\title{
Grape Pomace Aqueous Extract (GPE) Prevents High Fat Diet-Induced Diabetes and Attenuates Systemic Inflammation
}

\author{
Haiwen Li1,2, John Parry'1, Sarah Weeda', Shuxin Ren1, Thomas W. Castonguay2*, \\ Tai L. Guo ${ }^{3 *}$ \\ ${ }^{1}$ Agricultural Research Station, Virginia State University, Petersburg, VA, USA \\ ${ }^{2}$ Department of Nutrition and Food Science, University of Maryland, College Park, MD, USA \\ ${ }^{3}$ Department of Veterinary Biosciences and Diagnostic Imaging, College of Veterinary Medicine, \\ University of Georgia, Athens, GA, USA \\ Email: *twc@umd.edu, "tlguo1@uga.edu
}

Received 16 October 2015; accepted 26 June 2016; published 29 June 2016

Copyright (C) 2016 by authors and Scientific Research Publishing Inc.

This work is licensed under the Creative Commons Attribution International License (CC BY). http://creativecommons.org/licenses/by/4.0/

(c) (i) Open Access

\begin{abstract}
Diabetes mellitus is a group of metabolic syndromes with a hallmark of hyperglycemia. Serious long-term complications from diabetes are a major cause of hospitalization and death. We recently discovered that grape pomace, the by-product from the waste of the wine and juice industries, had great potential to prevent diabetes. In this study, we examined the potential use of grape pomace in controlling high blood glucose in the form of Cabernet Franc Grape pomace aqueous extract (GPE). Both streptozotocin (STZ; $1 \times 150 \mathrm{mg} / \mathrm{kg}$ )-treated mice and non-STZ treated mice were fed with high fat diet that was supplemented with $2.4 \mathrm{~g} / \mathrm{kg}$ GPE for 12 weeks. GPE had no significant effect on the blood glucose levels in STZ-treated mice. However, GPE significantly reduced blood glucose levels by $16.1 \%(p<0.05)$ in non-STZ treated mice following a 10 -week HFD feeding period when compared with high fat diet controls. GPE reduction of hyperglycemia also promoted a significant reduction of GHbA1c accumulation. Circulating peptide hormones related to glucose homeostasis, including GLP-1, glucagon, DPP-4 and insulin, were drastically altered by GPE. Moreover, GPE attenuated the expressions of insulin, glucagon, and several gut hormones at the mRNA level. In addition, GPE significantly down regulated 5 biomarker genes for systematic inflammation. Taken together, our results highlight a role of GPE as a potential alternative approach to control diabetes epidemic.
\end{abstract}

\section{Keywords}

Grape Pomace, Diabetes Mellitus, Gene Expression

\footnotetext{
${ }^{*}$ Corresponding authors.
}

How to cite this paper: Li, H.W., Parry, J., Weeda, S., Ren, S.X., Castonguay, T.W. and Guo, T.L. (2016) Grape Pomace Aqueous Extract (GPE) Prevents High Fat Diet-Induced Diabetes and Attenuates Systemic Inflammation. Food and Nutrition Sciences, 7, 647-660. http://dx.doi.org/10.4236/fns.2016.77066 


\section{Introduction}

Grape pomace is the main by-product of wine and juice production. It is primarily composed of skin, seed, pericarp, and fruit-stem; and it comprises approximately $25 \%$ of grape weight during grape processing. The complex phytochemicals (especially polyphenols) in grape pomace have attracted many scientists to study the potential of turning the by-product waste to a nutraceutical and value added product. Numerous phenolic compounds, especially flavonoids, are widely distributed in grapes. Many of these have been shown to have beneficial health effects. The most common phenolic compounds found in grapes with bioactivities are anthocyanins, flavonols, dihydroflavonols and proanthocyanidins [1]-[4]. Grape derived products are commercially available as overthe-counter medicines from many pharmacies and grocery stores. Animal and preclinical studies suggest that grape seed extract has preventive effects on certain metabolic syndromes and protects the cardiovascular system [1]. Furthermore, resveratrol is a major polyphenol that is thought to be a potential contributor of several beneficial properties of red wine [5] [6]. Resveratrol decreases insulin resistance, prevents heart failure, and prevents hypertension [6] [7]. It decreases the risk of cardiovascular disease [8], and reduces platelet adhesion, aggregation and generation of superoxide anion [9].

Diabetes is a group of metabolic syndromes with a hallmark of hyperglycemia. It is caused by an interruption in carbohydrate, protein and lipid metabolism. It is lack of insulin secretion and increase of insulin resistance [10]. The network of insulin, glucagon and multiple gastrointestinal hormones play key roles in the regulation of blood glucose homeostasis [11]. Glucagon-like peptides (GLP-1 and GLP-2) and glucose-dependent insulinotropic peptide (GIP) are the major incretins that stimulate the secretion of insulin [12]. GLPs are released from the lower gastrointestinal tract following food intake and play dual roles in the regulation of blood glucose concentrations through their concurrent insulin tropic and glucagonostatic actions (glucose-lowering effect). GIP is recognized as a physiologic regulator of food intake contributing to the control of obesity [13]. Energy balance and glucose homeostasis have become central targets for the design of pharmacological agents needed to prevent and treat diabetes.

Abundant evidence suggest that grape flavonoids play a key role in preventing the development of diabetes by acting as multi-target modulators that reduce oxidative stress, lower the degree of systematic inflammation [14] [15], and improve insulin resistance and anti-hyperglycemic effects. In obese mice, grape powder has been shown to acutely improve glucose tolerance and chronically reduce inflammation [16]. In streptozotocin (STZ)-induced diabetic rat models [17] [18], polyphenols in the grape could reduce body weight, food intake and hyperglycemia, and increase insulin sensitivity. Grape pomace byproducts from the Norton grape have been reported to contain significant amount of antioxidants [19], and consumption of Norton grape pomace for 3 months has exerted an anti-inflammatory effect in a diet induced mouse obesity model [20].

Diabetes can be manageable through a combination of diet, exercise and appropriate medications. Many plantbased products show promising effects on the management and prevention of diabetes. Producing healthy food or healthy agro-produced supplements could be a first line of defense against diabetes. However, the molecular mechanisms of such preventative properties are largely unknown. In our previous study [21], the grape pomace from the variety Tinta Cao was investigated. High antioxidant activities and inhibition of the proliferation of HT-29 and Caco-2 colon cancer cells through triggering apoptosis were demonstrated. We recently discovered that grape pomace had great potential to prevent diabetes. The in vitro action of grape pomace aqueous extract (GPE) in reducing postprandial hyperglycemia through inhibition of alpha-glucosidase was also demonstrated. In addition, in vivo studies with diabetic mice and healthy human subjects revealed GPE's effects on postprandial hyperglycemia, acute insulin secretion and lipid metabolism (unpublished, in preparation). However, neither the long-term effects of GPE on diabetes nor the molecular mechanisms involved have yet been fully elucidated. Such information is critical for its practical use in the prevention and management of diabetes. In our current study, the anti-diabetic properties of grape pomaces were investigated.

\section{Materials and Methods}

\subsection{Sample Preparation and Extractions}

Cabernet Franc grape pomace samples (fermented for 2 weeks) were obtained from Chrysalis Vineyards, Virginia in 2011. Grape pomace was air dried under low pressure and milled to 40 mesh size using a Scienceware Bel Art Micromill (Pequannock, NJ). The milled grape pomace was then extracted with water $(1: 10 \mathrm{~m} / \mathrm{v}) \mathrm{with}$ 
shaking at $200 \mathrm{rpm}$ for 2 hours at ambient temperature. Following extraction, the mixture was centrifuged at $4000 \mathrm{rpm}$ at $20^{\circ} \mathrm{C}$ for $30 \mathrm{~min}$. Supernatants were collected and freeze dried in the bench top freeze drier (AdVantage 2.0 BenchTop Freeze Dryer/Lyophilizer, SP Scientific) to obtain GPE.

\subsection{STZ and High Fat Diet (HFD)-Induction of Hyperglycemia in Mice}

Approximately sixteen-week old male C57BL/6NCr mice (National Cancer Institute, Frederick, MD, USA) with average body weight $29.6 \pm 1.8 \mathrm{~g}$ were housed in clean cages at 12 -hour light dark cycle at $20^{\circ} \mathrm{C}$ to $22^{\circ} \mathrm{C} \mathrm{C}$ with 5 mice/cage. Animal husbandry, care, and experimental procedures were approved by the Institutional Animal Care and Use Committee at University of Georgia. Streptozotocin was dissolved in ice-cold 100 mM sodium citrate buffer ( $\mathrm{pH} 4.5$ ) and injected intraperitoneally at a dose of $150 \mathrm{mg} / \mathrm{kg}$ body weight. A total of 24 STZtreated mice with fasting blood glucose higher than $120 \mathrm{mg} / \mathrm{dL}$ were used. 12 mice without STZ induction served as STZ treatment control. All 36 mice were maintained on rodent chow (8728C Teklad Certified Rodent Diet, Harlan Laboratories, Inc, Frederick, MD) until the experiment started. Two groups of STZ-treated mice (n $=12$ in each group) and non-STZ mice ( $n=6$ in each group) were fed with either 1) high fat diet (D04011601), or 2) high fat diet mixed with GPE at $2.4 \mathrm{~g} / \mathrm{kg}$ diet (D12121001). GPE dose was determined by following Hogan et al., 2011 [20]. The composition of the animal diet is summarized in Table 1. Mice were fed with their respective diets for 12 weeks with water available ad libitum. Approximately $5 \mu \mathrm{L}$ of whole blood was collected from the tail vein of each mouse once a week. Blood glucose was measured with a blood glucometer and accompanying test strips (ACCU-CHEK Meter ${ }^{\circledR}$, Roche Diagnostics, Kalamazoo, MI). Body weight was measured weekly.

\subsection{Animals and Tissue Collection}

At the end of the feeding study, diet was removed $12 \mathrm{~h}$ prior to sacrifice. Mice were anesthetized with $\mathrm{CO}_{2}$, and blood was collected by cardiac puncture into glass tubes for serum isolation. Separate plastic vials that had been previously rinsed with potassium EDTA solution were used for HbA1c measurements. The serum was separated after centrifugation at $1000 \times \mathrm{g}$ for $15 \mathrm{~min}$ at $4^{\circ} \mathrm{C}$ and stored for later use. Small intestine and pancreas were collected, immediately frozen in liquid nitrogen and stored in $-80^{\circ} \mathrm{C}$ for analysis.

\subsection{Mouse Glycated Hemoglobin (HbA1C) Determination}

Glycosylated (or glycated) hemoglobin (hemoglobin A1c, Hb1c, or HbA1c, A1C) is a form of hemoglobin used primarily to identify the average plasma glucose concentration over prolonged periods of time. It is commonly used as a golden rule for measurement of blood glucose management in type 2 diabetes. HbA1c was measured with a mouse glycated hemoglobin A1c (GHbA1c) ELISA Kit (Biotrend, CA, USA). Briefly, the microtiter plate was pre-coated with an antibody specific to GHbA1c. Standards or samples were then added to the appropriate microtiter plate wells with a biotin-conjugated polyclonal antibody preparation specific for GHbA1c and Avidin conjugated to Horse-radish Peroxidase (HRP), and incubated for 60 minutes. The TMB (3, 3, 5, 5' tetramethyl-benzidine) substrate solution was then added to each well following several washes. The enzyme-substrate reaction was terminated by the addition of a sulphuric acid solution and the color change was measured at a wavelength of $450 \mathrm{~nm} \pm 2 \mathrm{~nm}$ using a spectrophotometer. The concentration of GHbA1c in the samples was then determined by comparing the O.D. of the samples to the standard curve.

\subsection{RNA Isolation and Gene Expression Analysis}

Total RNA was extracted from small intestine and pancreas with RNeasy Plus Universal Mini Kit (Qiagen, Hilden, Germany) according to the manufacturer's instructions. The concentration and purity of RNA were determined by measuring the absorbance in a Nano drop spectrophotometer. Total RNA was treated with DNase I at room temperature for 15 min to remove genomic DNA contamination. RT2 First Strand Kit from Qiagen (Qiagen, Hilden, Germany) was used to synthesize first strand complementary DNA (cDNA). The gene expression levels were analyzed by Quantitative real-time RT-PCR conducted on the Bio-Rad CFX-96 Real-Time PCR System using RT2 SYBR Green Master mix (Bio-Rad Laboratories, Hercules, CA). The customized Mouse Diabetes $\mathrm{RT}^{2}$ Profiler ${ }^{\mathrm{TM}}$ PCR Array containing 84 genes related to the onset, development, and progression of diabetes was used to examine the expression patterns of the selected genes. The marker genes for diabetes and glucose homeostasis, inflammatory mediators tested are listed in Table 2. Hot-Start DNA Taq Polymerase was 
Table 1. Macronutrient and micronutrient content of the mouse diets.

\begin{tabular}{|c|c|c|c|c|}
\hline \multirow{3}{*}{$\begin{array}{c}\text { Product\# } \\
\%\end{array}$} & \multicolumn{2}{|c|}{ HFD } & \multicolumn{2}{|c|}{ HFD+GPE } \\
\hline & \multicolumn{2}{|c|}{ D04011601 } & \multicolumn{2}{|c|}{ D12121001 } \\
\hline & gm & kcal & gm & kcal \\
\hline Protein & 24 & 20 & 24 & 20 \\
\hline Carbohydrate & 41 & 35 & 41 & 35 \\
\hline Fat & 24 & 45 & 24 & 45 \\
\hline Total & & 100 & & 100 \\
\hline $\mathrm{kcal} / \mathrm{gm}$ & 4.7 & & 4.7 & \\
\hline Ingredient & gm & kcal & gm & kcal \\
\hline Casein,80Mesh & 200 & 800 & 200 & 800 \\
\hline L-Cystine & 3 & 12 & 3 & 12 \\
\hline CornStarch & 0 & 0 & 0 & 0 \\
\hline Maltodextrin10 & 100 & 400 & 100 & 400 \\
\hline Sucrose & 245.6 & 982 & 245.6 & 982 \\
\hline Cellulose,BW200 & 50 & 0 & 50 & 0 \\
\hline SoybeanOil & 25 & 225 & 25 & 225 \\
\hline Lard & 177.5 & 1598 & 177.5 & 1598 \\
\hline MineralMix S10026 & 10 & 0 & 10 & 0 \\
\hline MineralMix S10026B & 0 & 0 & 0 & 0 \\
\hline DiCalcium Phosphate & 13 & 0 & 13 & 0 \\
\hline CalciumCarbonate & 5.5 & 0 & 5.5 & 0 \\
\hline PotassiumCitrate,1H2O & 16.5 & 0 & 16.5 & 0 \\
\hline VitaminMix V10001 & 10 & 40 & 10 & 40 \\
\hline CholineBitartrate & 2 & 0 & 2 & 0 \\
\hline GrapeExtract & 0 & 0 & 2.07 & 0 \\
\hline FD\&CYellowDye\#5 & 0.05 & 0 & 0 & 0 \\
\hline FD\&C RedDye\#40 & 0 & 0 & 0 & 0 \\
\hline FD\&C BlueDye\#1 & 0 & 0 & 0.05 & 0 \\
\hline Total & 858.15 & 4057 & 860.22 & 4057 \\
\hline Grape Extract (g/kg) & $\mathbf{0}$ & & 2.4 & \\
\hline
\end{tabular}

Table 2. List of genes encoding different peptide hormones related to glucose homeostasis and inflammatory cytokines.

Peptide hormones related to glucose homeostasis: GLP-1, glucagon, insulin, GLP-1, DPP-4, GIP

Inflammatory mediators: PAI-1, resistin, IL-12 $\beta$, IL-6, TNF $\alpha$, INF- $\gamma$

activated by heating at $95^{\circ} \mathrm{C}$ for $10 \mathrm{~min}$ and real time PCR was conducted for 40 cycles $\left(15 \mathrm{~s} \mathrm{for} 95^{\circ} \mathrm{C}, 1 \mathrm{~min}\right.$ for $60^{\circ} \mathrm{C}$ ). All results were obtained from at least three independent biological repeats. Data were analyzed using the $\Delta \Delta \mathrm{CT}$ method [22]. Actin gene was used as the house-keeping gene for expression calculation. 


\subsection{Gene Expression Analysis at Protein Levels}

To further verify the expression changes at mRNA level, Bio-Plex Pro Diabetes Assays were conducted to get insight for the selected genes' expressions at the translational level using a Mouse Diabetes Multiplex magnetic bead-based multiplex assay kit by following the manufacturer's instruction (Bio-Rad, Hercules, CA). Plates were run on a Bio-Plex MAGPIX ${ }^{\mathrm{TM}}$ Multiplex Reader with Bio-Plex Manager ${ }^{\mathrm{TM}}$ MP Software (Luminex, Austin, TX). Each biomarker concentration was calculated as $\mathrm{pg} / \mathrm{ml}$. The levels of sensitivity in this panel were 0.64, 4.31, 0.59, 0.5, 68.29, 5.07, 2.98 and $184.89 \mathrm{pg} / \mathrm{ml}$ for ghrelin, GIP, GLP-1, glucagon, insulin, leptin, PAI-1 and resistin, respectively.

\subsection{Statistical Analysis}

All data collected, including blood glucose, ELISA and HbA1c, were expressed as mean \pm SE, and analyzed using one-way ANOVA followed by Bonferroni's multiple comparison post-hoc tests. Statistical significance was defined as $p \leq 0.05$.

\section{Results}

\subsection{Effect of Different Dietary Treatments on Blood Glucose and Body Weight}

STZ-treated mice and non-STZ treated mice were used to examine the efficacy of GPE on diabetes treatment and prevention. Figure 1 shows the effects of long-term consumption of GPE incorporated in a high fat diet on blood glucose. In STZ treated groups, there was no significant difference on blood glucose between the HFD fed and HFD+GPE fed mice. In non-STZ treated groups, at early treatment stages (first 4 weeks), there was no significant difference on blood glucose between HFD and HFD+GPE fed mice. However, after week 10, hyperglycemia was successfully induced by consumption of HFD diet with average blood glucose higher than 180 $\mathrm{mg} / \mathrm{dl}$. Importantly, consumption of GPE significantly inhibited such blood glucose increase induced by HFD. The blood glucose in HFD+GPE treatment group was $12.6 \%, 15.1 \%$ and $10.1 \%$ lower than that of HFD fed alone at week 8,10 and 12 respectively ( $p=0.07, p<0.01, p<0.05$, respectively). Furthermore, blood glucose of the HFD + GPE group did not differ across the 12-week experimental period. For body weight, no significant difference was observed among all groups during the 12-week feeding period (data not shown).

\subsection{Effect of Different Dietary Treatments on Glycated Hemoglobin, HbA1C}

HbA1C was measured at the end of the experiment (Figure 2). We observed a significant decrease (32.8\% at $p$ $<0.05$ ) in non-STZ treated mice fed with HFD + GPE compared to those fed with HFD only. No significant

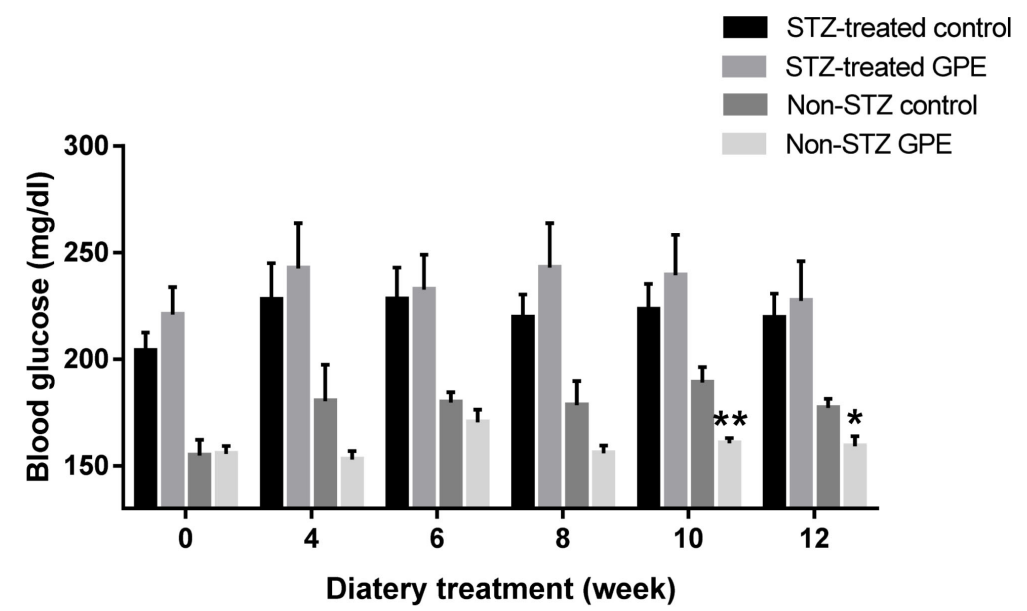

Figure 1. Effect of two different dietary treatments (with or without GPE) on blood glucose in STZ-treated and non-STZ mice. Blood glucose was expressed as the mean \pm SE $(n=6-20)$. Means of blood glucose at each time point with asterisk indicated significant difference between Non-STZ control and Non-STZ GPE group. *, $p<0.05$; **, $p<0.01$. 


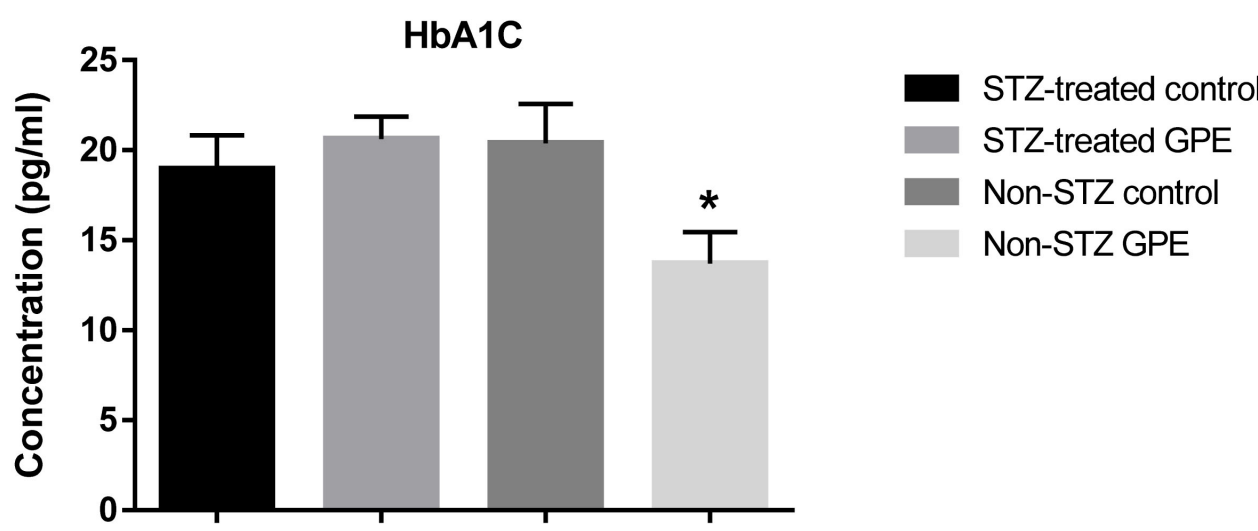

\section{Diatery treatment}

Figure 2. Effect of two different dietary treatments (with or without GPE) on glycated hemoglobin, HbA1C in STZ-treated and non-STZ mice. Glycated hemoglobin A1C was expressed as the mean \pm SE ( $\mathrm{n}=6-20$ ). Mean HbA1C for each group with * indicated significant difference between Non-STZ control and Non-STZ GPE group, $p<0.05$.

difference was observed between STZ-treated groups. As the level of plasma glucose increased, the fraction of glycated hemoglobin also increased.

\subsection{Effect of GPE on Peptide Hormones Related to Glucose Homeostasis}

Circulating peptide hormones such as glucagon, insulin, PAI-1 and resistin are important biomarkers for glucose homeostasis. We quantitatively examined the amount of these hormones in serum using the Bio-Plex Pro Diabetes Assay. GPE consumption did not affect these peptide hormone levels in STZ-treated mice. No significant differences were observed between STZ-treated mice fed with HFD and those fed with HFD+GPE. However, between non-STZ treated mouse groups, GPE significantly reduced serum levels of glucagon, PAI-1, insulin and resistin (Figure 3).

\subsection{RNA Expression Profile of the Peptide Hormones Regulating Glucose Homeostasis}

The mRNA expression profiles of the peptide hormones which potentially regulate glucose metabolism were also examined in non-STZ treated groups. These genes encoded peptide hormones, including glucagon, insulin, PAI-1, dipeptidylpeptidase-4 (DPP-4), GLP-1 and GIP. The expressions of glucagon, insulin and resistin were examined using pancreas RNA while PAI-1, DPP-4, GLP-1 and GIP were examined using small intestine RNA. As shown in Figure 4, long-term consumption of GPE downregulated the expression of glucagon $(39.1 \%, P<$ $0.05)$ and insulin (53.5\% at $P=0.07$ level) in pancreas. GPE also downregulated PAI-1 $(71.6 \%, P<0.05)$ and DPP-4 (46.7\%, $p<0.01)$ in small intestine. DPP-4 promotes the degradation of GLP-1 and GIP and enhances the release of glucagon [23]. Consistently, GLP-1 expression in small intestine was increased $44.7 \%(P<0.05)$ following consumption of GPE (Figure 4), while no significant change was observed for GIP expression (data not shown).

\subsection{GPE Reduced Inflammation Cytokines Expression}

Obesity is often considered as a systematic inflammation. During obesity development and its progression to hyperglycemia, various inflammation cytokines are expressed. To investigate the effect of GPE on systematic inflammation, we examined the expression changes of several inflammation mediators in the small intestine (Figure 5). Real-time RT-PCR showed that dietary GPE supplementation significantly suppressed the expression of inflammation cytokines TNF- $\alpha$, INF- $\gamma$ and IL-12 $\beta$ (Figure 5) by $63.3 \%, 38.4 \%$ and $64.8 \%$ respectively $(P<0.05)$. Resistin was $31.7 \%$ down, $(P<0.05)$ in pancreas. PAI-1 was also significantly downregulated $(71.6 \%$ down, $P<0.01$ ) by GPE consumption. No significant changes in IL-6 were observed. 


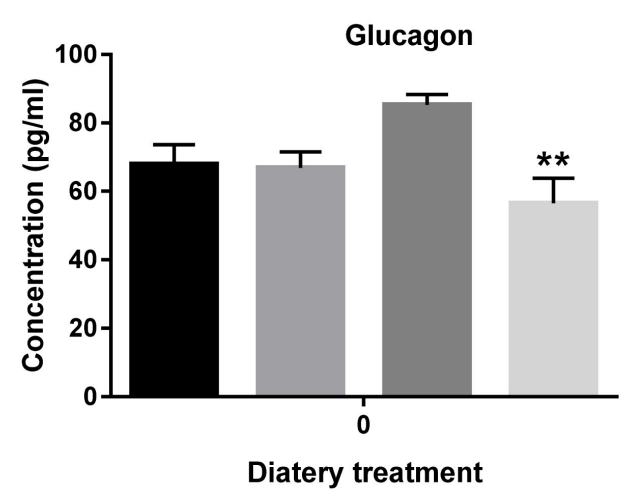

(a)

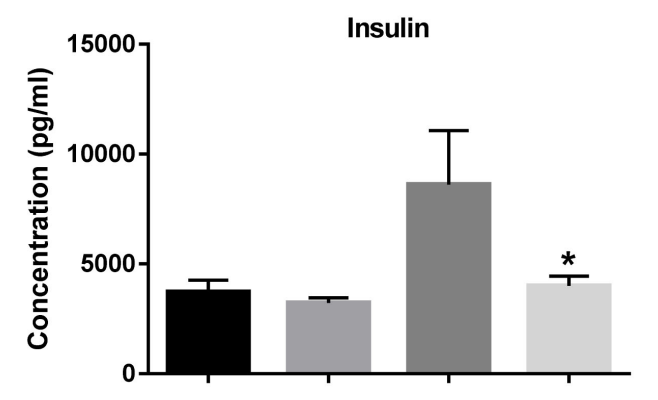

STZ-treated control

- STZ-treated GPE

Non-STZ control

Non-STZ GPE

Diatery treatment

(b)

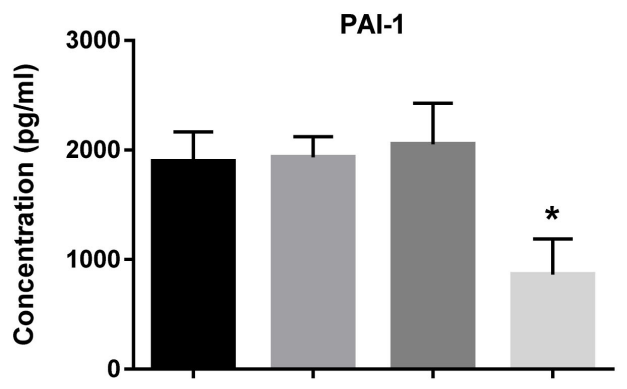

STZ-treated control

STZ-treated GPE

- Non-STZ control

Non-STZ GPE

Diatery treatment

(c)
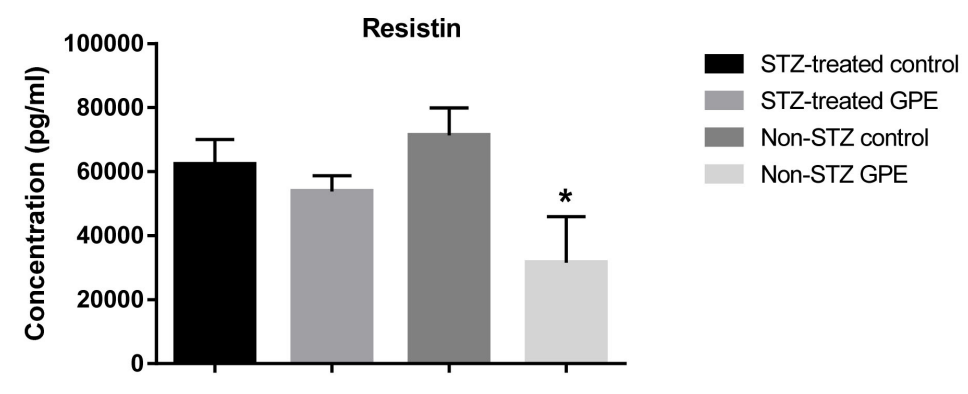

Diatery treatment

(d)

Figure 3. Effect of GPE on serum levels of insulin, glucagon, PAI1, resistin. Results were expressed as relative expression levels (mean \pm SEM, $n=6-12$ ). Significant difference between Non-STZ control and Non-STZ GPE group was marked with asterisk $(p<0.05)$. 
GLP-1

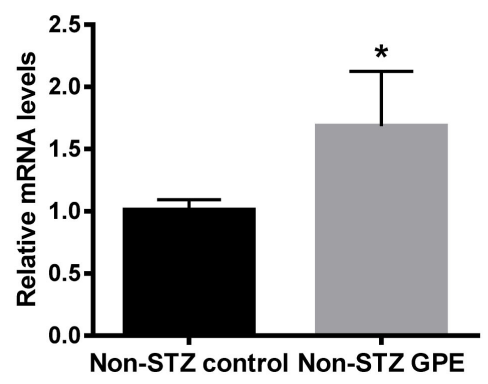

(a)

Dipeptidylpeptidase 4 (DPP-4)

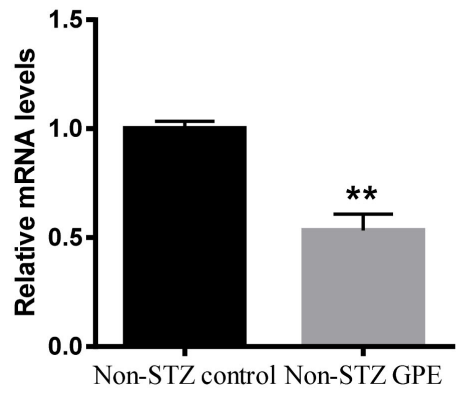

(c)
Glucagon

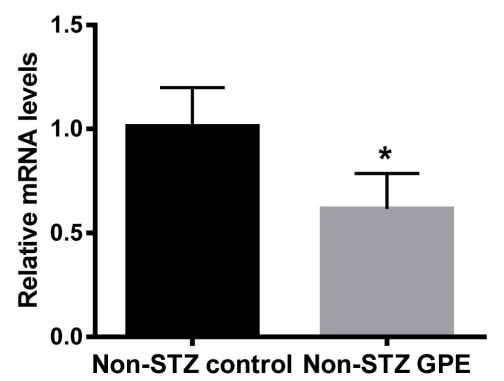

(b)

Insulin

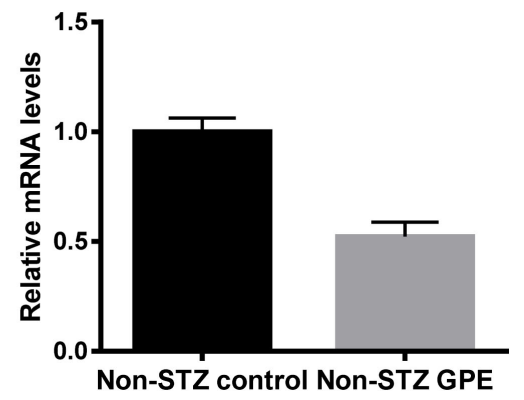

(d)

Figure 4. At mRNA levels, GPE affected peptide hormones which regulate blood glucose homeostasis in non-STZ mice. A-D: GLP-1, glucagon, DPP-4 and insulin gene, respectively. Pancreas and small intestine were harvested from animals on different diets, total mRNA was extracted, and the mRNA level was determined using real-time PCR. Results are expressed as relative expression levels (mean \pm $\mathrm{SEM}, \mathrm{n}=6$ ) to control. Columns marked with * are significantly different from each other at $p \leq 0.05$.

TNF $\alpha$

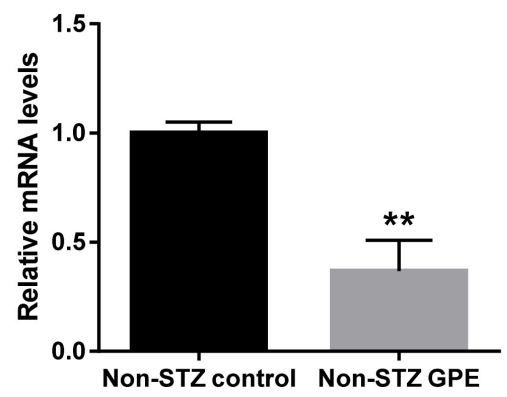

(a)

Interleukin-12 $\beta$ (IL-12 $\beta$ )

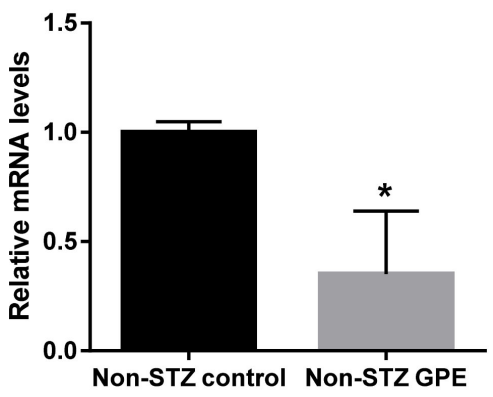

(c)

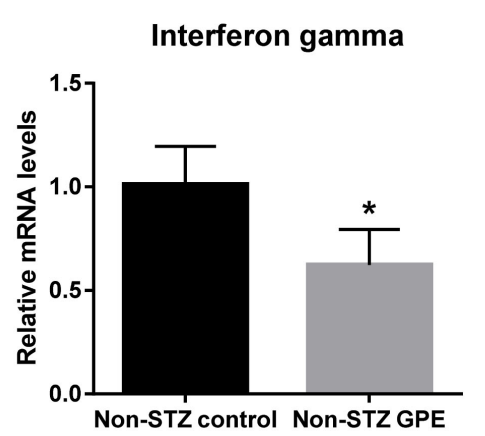

(b)

PAI-1

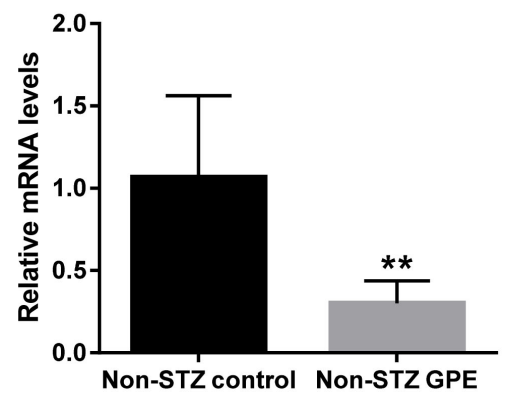

(d) 


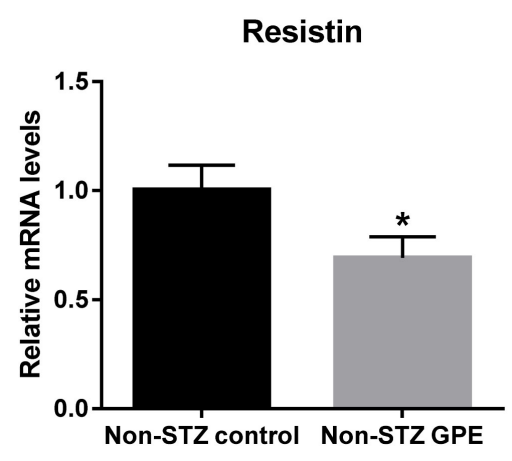

(e)

\begin{abstract}
Figure 5. Effects of GPE on inflammatory mediator genes in small intestine and pancreas. Pancreas and small intestine were harvested from animals on different diets, total mRNA was extracted, and the mRNA level was determined using real-time RT-PCR. Results are expressed as relative expression levels (mean $\pm \mathrm{SEM}, \mathrm{n}=6$ ) to control. Columns marked with * are significantly different from each other at $p \leq 0.05$.
\end{abstract}

\title{
4. Discussion
}

A growing body of evidence suggests that the consumption of grapes and/or grape derived food products rich in polyphenols promotes a variety of health effects. Grape products show beneficial effects in preventing the development of metabolic syndromes, particularly diabetes, obesity and heart disease [24]-[28]. In our previous studies (unpublished, in preparation), grape pomace water extract showed a dose-dependent inhibition of $\alpha$ glucosidase activity and significantly decreased blood glucose in diabetic mice and normal human subjects within 3 hours of GPE consumption. In addition, GPE delayed carbohydrate digestion, absorption and transportat to the blood stream. These results prompted us to examine the long-term effects of GPE in regulating carbohydrate metabolism and to elucidate the molecular mechanism(s) involved.

In this study, we found that GPE did not play a critical role on STZ-treated mice during the 12-week feeding period, although there was a slight reduction in blood glucose at week 8. In our previous studies using a modified $2 \mathrm{~h}$ Oral glucose Tolerant Test, STZ-treated mice gavaged with GPE-corn starch suspension resulted in a significant decrease in postprandial blood glucose compared with the STZ-treated mice only gavaged with corn starch (unpublished, in preparation). Taken together, our results suggest that GPE could suppress acute blood glucose but long-term consumption of GPE would not help treat diabetes. Interestingly, when we fed GPE to non-STZ treated mice supplied with HFD, we found that GPE had significant effects on preventing HFD-induced hyperglycemia. Circulating peptide hormones in the blood and HbA1c were also dramatically altered by GPE. Further, RNA expression of several peptide hormones related to glucose homeostasis were significantly changed by GPE. In addition, biomarker genes for systematic inflammation were also altered by GPE. These results suggest that daily consumption of GPE might prevent hyperglycemia caused by high fat diet. Similar evidence was obtained by Laight et al. [29] who reported that consumption of grape seed extract for 4 weeks significantly improved markers of inflammation and glycaemia in obese Type 2 diabetic subjects with 32 patients involved in a double blind randomized placebo controlled trial.

To elucidate the molecular mechanisms involved in blood glucose lowering properties of the GPE, we further evaluated the effects of GPE on theglucose homeostasis. Glucose homeostasis was primarily governed by the two counteracting hormones: the glucose-elevating hormone glucagon and the glucose-lowering hormone insulin [11]. Disruption of the equilibration by augmented secretion of glucagon and decreased secretion of insulin typically promotes commenced postprandial hyperglycemia [30] [31]. Incretins, such as GLP-1, GIP and DPP-4, stimulate insulin secretion from pancreatic $\beta$ cells [30] [32]-[34]; GLP-1 inhibits glucagon release from the alpha cells of the islets of Langerhans, while GIP enhances glucagon secretion [30] [32]-[38]. Both GLP-1 and GIP are rapidly degraded by the enzyme DPP-4 [39]-[41]. Mice fed diet that was supplemented with GPE significantly decreased glucagon expression in this study. On the other hand, GLP-1 expression wassignificantly increased, which is consistent with the observation that DPP-4 expression was significantly decreased by GPE consumption. Numerous studies are in agreement with these findings. It has been reported that grape seed extract enriched in procyanidins (GSPE) improves glycemia by affecting the insulin release and decreasing glu- 
cose levels in Wistar female rats, increasing the active form of GLP-1 and inhibiting intestinal DPP-4 activity [42]-[44].

Accumulating evidence indicates that grape polyphenols work in many different ways to decrease blood glucose [45], improve insulin resistance [46]-[48], suppress hyperinsulinemia [49], and reduce blood pressure and lipid concentration [50]-[53]. Consistently, our results showed that the plasma glucose and insulin mRNA expression was significantly decreased in the non-STZ treated mice fed with GPE. Consumption of a high fat diet can increase body fat deposition, diminish glucose uptake and consumption in skeletal muscle, and consequently increase insulin resistance [54]-[57]. Adipose tissue also increases the amount of adipocytes and produces several hormones and cytokines that affect glucose homeostasis and fat metabolism [58] [59]. For example, resistin, a cysteine-rich adipose-derived peptide hormone, potentially links obesity and insulin resistance [60]. In rodents, exposure to resistin results in decreased response to insulin [61]. Conversely, acute administration of resistin impairs glucose tolerance and insulin action [62]. Our study demonstrated that GPE had a decreasing effect on circulating and mRNA expression level of resistin. This might contribute to an improvement of glucose metabolism and insulin resistance.

Additional evidence indicate that excessive fatty acid consumption in high fat diets results in excessive lipid accumulation in adipose and peripheral tissues, and subsequent chronic low-grade systemic inflammation [15] [63] reported that grape powder extract rich in phenolic phytochemicals possess anti-oxidant and anti-inflammatory properties. It attenuated TNF $\alpha$-mediated inflammation through inhibiting the expression of IL-6, IL-1 $\beta$, IL-8, MCP-1, COX-2 and TLR-2 and improves insulin resistance in primary cultures of newly differentiated human adipocytes. Increased expression of TNF- $\alpha$ mRNA in white adipose tissue in obese humans has a strong positive correlation with the level of hyperinsulinemia and can lead to insulin resistance [64] [65]. In our study, the mRNA expression levels of inflammation cytokine/adipokines genes including PAI-1, TNF- $\alpha$, INF- $\gamma$ and IL-12 $\beta$ in small intestine were significantly suppressed by GPE consumption while IL-6 showed no significant difference. Similar to our findings, HFD-induced obese mice supplemented with the Norton grape pomace (250 $\mathrm{mg} / \mathrm{kg}$ body weight for 12 weeks) exhibited less oxidative stress [19], and that one-year consumption of grape extract downregulated the expression of key pro-inflammatory cytokines [66].

Understanding the specific composition of the GPE is an important aspect and should be the focus of future studies.

\section{Conclusion}

Our main goal was to investigate the effects of a dietary grape pomace extract supplement on the prevention of hyperglycemia and diabetes. This study provides important evidence that long-term consumption of GPE can: 1) lower the blood glucose and improve HbA1c; 2) down-regulate the expression of several cytokines involved in chronic low-grade inflammation triggered by high fat diet, and 3) attenuate insulin resistance in HFD-induced diabetic mice, but not in STZ-treated mice. It is likely that GPE has more beneficial effects on diabetes prevention instead of its treatment.

\section{Acknowledgements}

These studies were supported by the Capacity Building Grant (20076) from the U.S. Department of Agriculture (USDA), and in part by NIH R21ES24487.

\section{References}

[1] Georgiev, V., Ananga, A. andTsolova, V. (2014) Recent Advances and Uses of Grape Flavonoids as Nutraceuticals. Nutrients, 6, 391-415. http://dx.doi.org/10.3390/nu6010391

[2] Chacona, M.R., Ceperuelo-Mallafrea, V., Maymo-Masipa, E., Mateo-Sanzb, J., Arolac, L., Guitierreza, C., FernandezReald, J., Ardevolc, A., Simona, I. and Vendrella, J. (2009) Grape-Seed Procyanidins Modulate Inflammation on Human Differentiated Adipocytes in Vitro. Cytokine, 47, 137-142. http://dx.doi.org/10.1016/j.cyto.2009.06.001

[3] Bagchi, D., Bagchi, M., Stohs, S., Das, D., Ray, C., Kuszynski, S. and Joshi, H. (2000) Free Radicals and Grape Seed Proanthocyanidin Extract: Importance in Human Health and Disease Prevention. Toxicology, 148, 187-197. http://dx.doi.org/10.1016/s0300-483x(00)00210-9

[4] Cantos, E., Espin, J. and Tomas-Barberan, F. (2002) Varietal Differences among the Polyphenol Profiles of Seven Table Grape Cultivars Studied by LC-DAD-MS-MS. Journal of Agricultural and Food Chemistry, 50, 5691-5696. http://dx.doi.org/10.1021/jf0204102 
[5] Tome-Carneiro, J., Gonzalvez, M., Larrosa, M., Garcia-Almagro, F., Aviles-Plaza, F., Parra, S., Yanez-Gascon, M., Ruiz-Ros, J., Garcia-Conesa, M., Tomas-Barberan, F. and Espin, J. (2012) Consumption of a Grape Extract Supplement Containing Resveratrol Decreases Oxidized LDL and ApoB in Patients Undergoing Primary Prevention of Cardiovascular Disease: A Triple-Blind, 6-Month Follow-Up, Placebo-Controlled, Randomized Trial. Molecular Nutrition \& Food Research, 56, 810-821. http://dx.doi.org/10.1002/mnfr.201100673

[6] Bertelli, A., Bertelli, A.A., Gozzini, A. andGiovannini, L. (1998) Plasma and Tissue Resveratrol Concentrations and Pharmacological Activity. Drugs under Experimental and Clinical Research, 24, 133-138.

[7] Petrovski, G., Gurusamy, N. and Das, D. (2011) Resveratrol in Cardiovascular Health and Disease. Annals of the New York Academy of Sciences, 1215, 22-33. http://dx.doi.org/10.1111/j.1749-6632.2010.05843.x

[8] Dell Agli, M., Galli, G., Vrhovsek, U., Mattivi, F. and Bosisio, E. (2005) In Vitro Inhibition of Human cGMP-Specific Phosphodiesterase- 5 by Polyphenols from Red Grapes. Journal of Agricultural and Food Chemistry, 53, 1960-1965. http://dx.doi.org/10.1021/jf048497+

[9] Olas, B., Wachowicz, B., Tomczak, A., Erler, J., Stochmal, A. andOleszek, W. (2008) Comparative Anti-Platelet and Antioxidant Properties of Polyphenol-Rich Extracts from: Berries of Aronia melanocarpa, Seeds of Grape and Bark of Yucca schidigera in Vitro. Platelets, 19, 70-77. http://dx.doi.org/10.1080/09537100701708506

[10] Stumvoll, M., Goldstein, B. andHaeften, T. (2005) Type 2 Diabetes: Principles of Pathogenesis and Therapy. Lancet, 365, 1333-1346. http://dx.doi.org/10.1016/S0140-6736(05)61032-X

[11] Aronoff, S., Berkowitz, K., Schreiner, B. and Want, L. (2004) Glucose Metabolism and Regulation: Beyond Insulin and Glucagon. Diabetes Spectrum, 17, 183-190. http://dx.doi.org/10.2337/diaspect.17.3.183

[12] Zunz, E. and La Barre, J. (1929) Contributiona a l'etude des variations physiologiques de la secretion interne du pancreas: relations entre les secretions externe et interne du pancreas. Archives Internationales de Physiologie, 31, 162-179.

[13] Arora, S. and Anubhuti (2006) Role of Neuropeptides in Appetite Regulation and Obesity-A Review. Neuropeptides, 40, 375-401. http://dx.doi.org/10.1016/j.npep.2006.07.001

[14] Tsuda, T. (2012) Dietary Anthocyanin-Rich Plants: Biochemical Basis and Recent Progress in Health Benefits Studies. Molecular Nutrition \& Food Research, 56, 159-170. http://dx.doi.org/10.1002/mnfr.201100526

[15] Chuang, C. and McIntosh, M. (2011) Potential Mechanisms by which Polyphenol-Rich Grapes Prevent Obesity-Mediated Inflammation and Metabolic Diseases. Annual Review of Nutrition, 31, 155-176. http://dx.doi.org/10.1146/annurev-nutr-072610-145149

[16] Chuang, C., Bumrungpert, A., Kennedy, A., Overman, A., West, T., Dawson, B. and McIntosh, M. (2012) Grape Powder Extract Attenuates Tumor Necrosis Factor $\alpha$-Mediated Inflammation and Insulin Resistance in Primary Cultures of Human Adipocytes. The Journal of Nutritional Biochemistry, 22, 89-94. http://dx.doi.org/10.1016/j.jnutbio.2009.12.002

[17] Al-Awwadi, N., Azay, J., Poucheret, P., Cassanas, G., Krosniak, M. and Auger, C. (2004) Antidiabetic Activity of Red Wine Polyphenolic Extract, Ethanol, or Both in Streptozotocin-Treated Rats. Journal of Agricultural and Food Chemistry, 52, 1008-1016. http://dx.doi.org/10.1021/jf030417z

[18] Al-Awwadi, N., Bornet, A., Azay, J., Araiz, C., Delbosc, S., Cristol, J., Linck, N., Cros, G. and Teissedre, P. (2004) Red Wine Polyphenols Alone or in Association with Ethanol Prevent Hypertension, Cardiac Hypertrophy, and Production of Reactive Oxygen Species in the Insulinresistant Fructose-Fed Rat. Journal of Agricultural and Food Chemistry, 52, 5593-5597. http://dx.doi.org/10.1021/jf049295g

[19] Hogan, S., Canning, C., Sun, S., Sun, X. and Zhou, K. (2010) Effects of Grape Pomace Antioxidant Extract on Oxidative Stress and Inflammation in Diet Induced Obese Mice. Journal of Agricultural and Food Chemistry, 58, 1125011256. http://dx.doi.org/10.1021/jf102759e

[20] Hogan, S., Canning, C., Sun, S., Sun, X., Kadouh, H. and Zhou, K. (2011) Dietary Supplementation of Grape Skin Extract Improves Glycemia and Inflammation in Diet-Induced Obese Mice Fed a Western High Fat Diet. Journal of Agricultural and Food Chemistry, 59, 3035-3041. http://dx.doi.org/10.1021/jf1042773

[21] Parry, J., Li, H., Liu, J., Zhou, K., Zhang, L. and Ren, S. (2011) Antioxidant Activity, Antiproliferation of Colon Cancer Cells, and Chemical Composition of Grape Pomace. Food and Nutrition Sciences, 2, 530-540. http://dx.doi.org/10.4236/fns.2011.26076

[22] Livak, K. and Schmittgen, T. (2001) Analysis of Relative Gene Expression Data Using Real-Time Quantitative PCR and the $2^{-\Delta \Delta C T}$ Method. Methods, 25, 402-408. http://dx.doi.org/10.1006/meth.2001.1262

[23] Kim, W. and Egan, J. (2008) The Role of Incretins in Glucose Homeostasis and Diabetes Treatment. Pharmacological Reviews, 60, 470-512. http://dx.doi.org/10.1124/pr.108.000604

[24] El-Alfy, A., Ahmed, A. and Fatani, A. (2005) Protective Effect of Red Grape Seeds Proanthocyanidins against Induction of Diabetes by Alloxan in Rats. Pharmacological Reviews, 52, 264-270. 
[25] Kim, H., Bartley, G., Arvik, T., Lipson, R., Nah, S. and Seo, K. (2014) Dietary Supplementation of Chardonnay Grape Seed Flour Reduces Plasma Cholesterol Concentration, Hepatic Steatosis, and Abdominal Fat Content in High-Fat Diet-Induced Obese Hamsters. Journal of Agricultural and Food Chemistry, 62, 1919-1925. http://dx.doi.org/10.1021/jf404832s

[26] Kim, H., Kim, D., Seo, K., Chon, J., Nah, S., Bartley, G., Arvik, T., Lipson, R. and Yokoyama, W. (2015) Modulation of the Intestinal Microbiota Is Associated with Lower Plasma Cholesterol and Weight Gain in Hamsters Fed Chardonnay Grape Seed Flour. Journal of Agricultural and Food Chemistry, 63, 1460-1467. http://dx.doi.org/10.1021/jf5026373

[27] Pezzuto, J.M. (2008) Grapes and Human Health: A Perspective. Journal of Agricultural and Food Chemistry, 56, 6777-6784. http://dx.doi.org/10.1021/jf800898p

[28] Seeram, N.P. (2008) Berry Fruits: Compositional Elements, Biochemical Activities, and the Impact of Their Intake on Human Health, Performance, and Disease. Journal of Agricultural and Food Chemistry, 56, 627- 629. http://dx.doi.org/10.1021/jf071988k

[29] Laight, K., Rooprai, H., Shaw, K. and Cummings, M. (2009) Effects of Grape Seed Extract in Type 2 Diabetic Subjects at High Cardiovascular Risk: A Double Blind Randomized Placebo Controlled Trial Examining Metabolic Markers, Vascular Tone, Inflammation, Oxidative Stress and Insulin Sensitivity. Diabetic Medicine, 26, 526-531. http://dx.doi.org/10.1111/j.1464-5491.2009.02727.x

[30] Yabe, D., Kuroe, A., Watanabe, K., Iwasaki, M., Hamasaki, A., Hamamoto, Y., Harada, N., Yamane, S., Lee, S., Murotani, K., Deacon, C., Holst, J., Hirano, T., Inagaki, N., Kurose, T. and Seino, Y. (2015) Early Phase Glucagon and Insulin Secretory Abnormalities, but Not Incretin Secretion, Are Similarly Responsible for Hyperglycemia after Ingestion of Nutrients. Journal of Diabetes and Its Complications, 29, 413-421. http://dx.doi.org/10.1016/j.jdiacomp.2014.12.010

[31] Unger, R. and Cherrington, A. (2012) Glucagonocentric Restructuring of Diabetes: A Pathophysiologic and Therapeutic Makeover. Journal of Clinical Investigation, 122, 4-12. http://dx.doi.org/10.1172/JCI60016

[32] Drucker, D. (2013) Incretin Action in the Pancreas: Potential Promise, Possible Perils, and Pathological Pitfalls. Diabetes, 62, 3316-3323. http://dx.doi.org/10.2337/db13-0822

[33] Holst, J. (2007) The Physiology of Glucagon-Like Peptide 1. Physiological Reviews, 87, 1409-1439. http://dx.doi.org/10.1152/physrev.00034.2006

[34] Seino, Y. and Yabe, D. (2013) GIP and GLP-1: Incretin Actions beyond Pancreas. Journal of Diabetes Investigation, 4, 108-130. http://dx.doi.org/10.1111/jdi.12065

[35] Christensen, M., Calanna, S. and Sparre-Ulrich, A. (2014) Glucose-Dependent Insulinotropic Polypeptide Augments Glucagon Responses to Hypoglycemia in Type 1 Diabetes. Diabetes, 64, 72-78. http://dx.doi.org/10.2337/db14-0440

[36] Christensen, M., Vedtofte, L. and Holst, J. (2011) Glucose-Dependent Insulinotropic Polypeptide: A Bifunctional Glucose-Dependent Regulator of Glucagon and Insulin Secretion in Humans. Diabetes, 60, 3103-3109. http://dx.doi.org/10.2337/db11-0979

[37] Mentis, N., Vardarli, I. and Kothe, L. (2011) GIP Does Not Potentiate the Antidiabetic Effects of GLP-1 in Hyperglycemic Patients with Type 2 Diabetes. Diabetes, 60, 1270-1276. http://dx.doi.org/10.2337/db10-1332

[38] Taminato, T., Seino, Y. and Goto, Y. (1977) Synthetic Gastric Inhibitory Polypeptide. Stimulatory Effect on Insulin and Glucagon Secretion in the Rat. Diabetes, 26, 480-484. http://dx.doi.org/10.2337/diab.26.5.480

[39] McIntosh, C., Demuth, H., Pospisilik, J. and Pederson R. (2005) Dipeptidyl Peptidase IV Inhibitors: How Do They Work as New Antidiabetic Agents? Regulatory Peptides, 128, 159-165. http://dx.doi.org/10.1016/j.regpep.2004.06.001

[40] Behme, M., Dupré, J. and McDonald, T. (2003) Glucagon-Like Peptide 1 Improved Glycemic Control in Type 1 Diabetes. BMC Endocrine Disorders, 3, 3. http://dx.doi.org/10.1186/1472-6823-3-3

[41] Dupre, J., Behme, M., Hramiak, I., McFarlane, P., Williamson, M., Zabel, P. and McDonald, T. (1995) Glucagon-Like Peptide I Reduces Postprandial Glycemic Excursions in IDDM. Diabetes, 44, 626-630. http://dx.doi.org/10.2337/diab.44.6.626

[42] González-Abuín, N., Martínez-Micaelo, N., Blay, M., Ardévol, A. and Pinent, M. (2014) Grape-Seed Procyanidins Prevent the Cafeteria-Diet-Induced Decrease of Glucagon-Like Peptide-1 Production. Journal of Agricultural and Food Chemistry, 62, 1066-1072. http://dx.doi.org/10.1021/jf405239p

[43] González-Abuín, N., Martínez-Micaelo, N., Blay, M., Green, B., Pinent, M. and Ardévol, A. (2014) Grape-Seed Procyanidins Modulate Cellular Membrane Potential and Nutrient-Induced GLP-1 Secretion in STC-1 Cells. American Journal of Physiology-Cell Physiology, 306, C485-C492. http://dx.doi.org/10.1152/ajpcell.00355.2013

[44] González-Abuín, N., Martínez-Micaelo, N., Blay, M., Pujadas, G., Garcia-Vallvé, S., Pinent, M. and Ardévol, A. (2012) Grape Seed-Derived Procyanidins Decrease Dipeptidyl-Peptidase 4 Activity and Expression. Journal of Agricultural and Food Chemistry, 60, 9055-9061. http://dx.doi.org/10.1021/jf3010349 
[45] Zhang, L., Hogan, S., Li, J., Sun, S., Canning, C. Zheng, S. and Zhou, K. (2011) Grape Skin Extract Inhibits Mammalian Intestinal $\alpha$-Glucosidase Activity and Suppresses Postprandial Glycemic Response in Streptozocin-Treated Mice. Food Chemistry, 126, 466-471. http://dx.doi.org/10.1016/j.foodchem.2010.11.016

[46] Baur, J., Pearson, K., Price, N., Jamieson, H., Lerin, C., Kalra, A., Prabhu, V., Allard, S. and Lopez-Lluch, G. (2004) Resveratrol Improves Health and Survival of Mice on a High-Calorie Diet. Nature, 444, 337-342. http://dx.doi.org/10.1038/nature05354

[47] Sun, C., Zhang, F., Ge, X., Yan, T., Chen, X. and Shi, X. (2007) SIRT1 Improves Insulin Sensitivity under Insulin Resistance Conditions by Repressing PTP1B. Cell Metabolism, 6, 307-319. http://dx.doi.org/10.1016/j.cmet.2007.08.014

[48] Lagouge, M., Argmann, C., Gerhart-Hines, Z., Meziane, H., Lerin, C. and Daussin, F. (2006) Resveratrol Improves Mitochondrial Function and Protects against Metabolic Disease by Activating SIRT1 and PGC-1Alpha. Cell, 127, 1109-1122. http://dx.doi.org/10.1016/j.cell.2006.11.013

[49] Hokayem, M., Blond, E., Vidal, H., Lambert, K., Meugnier, E., Feillet-Coudray, C., Coudray, C., Pesenti, S., Luyton, C., Lambert-Porcheron, S., Sauvinet, V., Fedou, C., Brun, J., Rieusset, J., Bisbal, C., Sultan, A., Mercier, J., Goudable, J., Dupuy, A., Cristol, J., Laville, M. and Avignon, A. (2013) Grape Polyphenols Prevent Fructose-Induced Oxidative Stress and Insulin Resistance in First-Degree Relatives of Type 2 Diabetic Patients. Diabetes Care, 36, 1454-1461. http://dx.doi.org/10.2337/dc12-1652

[50] Perez-Jimenez, J. and Saura-Calixto, F. (2008) Grape Products and Cardiovascular Disease Risk Factors. Nutrition Research Reviews, 21, 158-173. http://dx.doi.org/10.1017/S0954422408125124

[51] Vislocky, L. and Fernandez, M. (2010) Biomedical Effects of Grape Products. Nutrition Reviews, 68, 656-670. http://dx.doi.org/10.1111/j.1753-4887.2010.00335.x

[52] Schini-Kerth, V., Auger, C., Kim, J., Etienne-Selloum, N. and Chataigneau, T. (2010) Nutritional Improvement of the Endothelial Control of Vascular Tone by Polyphenols: Role of NO and EDHF. Pflügers Archiv, 459, 853-862. http://dx.doi.org/10.1007/s00424-010-0806-4

[53] Barona, J., Aristizabal, J., Blesso, C., Volek, J. and Fernandez, M. (2012) Grape Polyphenols Reduce Blood Pressure and Increase Flow-Mediated Vasodilation in Men with Metabolic Syndrome. Journal of Nutrition, 142, 1626-1632. http://dx.doi.org/10.3945/jn.112.162743

[54] Lovejoy, J., Champagne, C., Smith, S., DeLany, J., Bray, G. and Lefvre, M. (2001) Relationship of Dietary Fat and Serum Cholesterol Ester and Phospholipid Fatty Acids to Markers of Insulin Resistance in Men and Women with a Range of Glucose Tolerance. Metabolism, 50, 86-92. http://dx.doi.org/10.1053/meta.2001.19440

[55] Mayer-Davis, E., Monaco, J., Hoen, H., Carmichael, S., Vitolins, M. and Rewers, M. (1997) Dietary Fat and Insulin Sensitivity in a Triethnic Population: The Role of Obesity: The Insulin Resistance Atherosclerosis Study (IRAS). The American Journal of Clinical Nutrition, 65, 79-87.

[56] Flanagan, A., Brown, J., Santiago, C., Aad, P. and Spicer, L. (2008) Spicer M.T. High-Fat Diets Promote Insulin Resistance through Cytokine Gene Expression in Growing Female Rats. The Journal of Nutritional Biochemistry, 19, 505-513. http://dx.doi.org/10.1016/j.jnutbio.2007.06.005

[57] Tanaka, S., Hayashi, T., Toyoda, T., Hamada, T., Shimizu, Y., Hirata, M., Ebihara, K., Masuzaki, H., Hosoda, K., Fushiki, T. and Nakao, K. (2007) High-Fat Diet Impairs the Effects of a Single Bout of Endurance Exercise on Glucose Transport and Insulin Sensitivity in Rat Skeletal Muscle. Metabolism, 56, 1719-1728. http://dx.doi.org/10.1016/j.metabol.2007.07.017

[58] Ahima, R. and Flier, J. (2000) Adipose Tissue as an Endocrine Organ. Trends in Endocrinology and Metabolism, 11, 327-332. http://dx.doi.org/10.1016/S1043-2760(00)00301-5

[59] Trujillo, M. and Scherer, P. (2006) Adipose Tissue-Derived Factors: Impact on Health and Disease. Endocrine Reviews, 27, 762-778. http://dx.doi.org/10.1210/er.2006-0033

[60] Barnes, K. and Miner, J. (2009) Role of Resistin in Insulin Sensitivity in Rodents and Humans. Current Protein \& Peptide Science, 10, 96-107. http://dx.doi.org/10.2174/138920309787315239

[61] Rangwalam, S., Richm, A., Rhoadesm, B., Shapirom, J., Obicim, S., Rossettim, L. and Lazarm, M. (2004) Abnormal Glucose Homeostasis Due to Chronic Hyperresistinemia. Diabetes, 53, 1937-1941. http://dx.doi.org/10.2337/diabetes.53.8.1937

[62] Kim, K., Lee, K., Moon, Y. and Sul, H. (2001) A Cysteine-Rich Adipose Tissue-Specific Secretory Factor Inhibits Adipocyte Differentiation. The Journal of Biological Chemistry, 276, 11252 -11256. http://dx.doi.org/10.1074/jbc.C100028200

[63] Ouchi, N., Parker, J., Lugus, J. and Walsh, K. (2011) Adipokines in Inflammation and Metabolic Disease. Nature Reviews Immunology, 11, 85-97. http://dx.doi.org/10.1038/nri2921

[64] Hotamisligil, G., Arner, P., Caro, J., Atkinson, R. and Spiegelman, B. (1995) Increased Adipose Expression of Tumor Necrosis Factor-Alpha in Human Obesity and Insulin Resistance. Journal of Clinical Investigation, 95, 2409-2415. http://dx.doi.org/10.1172/JCI117936 
[65] Hotamisligil, G., Shargill, N. and Spiegelman, B. (1993) Adipose Expression of Tumor Necrosis Factor-Alpha: Direct Role in Obesity-Linked Insulin Resistance. Science, 259, 87-91. http://dx.doi.org/10.1126/science.7678183

[66] Tomé-Carneiro, J., Gonzálvez, M., Larrosa, M., Yáñez-Gascón, M., García-Almagro, F., Ruiz-Ros, J., Tomás-Barberán, F., García-Conesa. M. and Espín. J. (2013) Grape Resveratrol Increases Serum Adiponectin and Downregulates Inflammatory Genes in Peripheral Blood Mononuclear Cells: A Triple-Blind, Placebo-Controlled, One-Year Clinical Trial in Patients with Stable Coronary Artery Disease. Cardiovascular Drugs and Therapy, 27, 37-48.

http://dx.doi.org/10.1007/s10557-012-6427-8

\section{Submit or recommend next manuscript to SCIRP and we will provide best service for you:}

Accepting pre-submission inquiries through Email, Facebook, Linkedin, Twitter, etc A wide selection of journals (inclusive of 9 subjects, more than 200 journals)

Providing a 24-hour high-quality service

User-friendly online submission system

Fair and swift peer-review system

Efficient typesetting and proofreading procedure

Display of the result of downloads and visits, as well as the number of cited articles

Maximum dissemination of your research work

Submit your manuscript at: http://papersubmission.scirp.org/ 